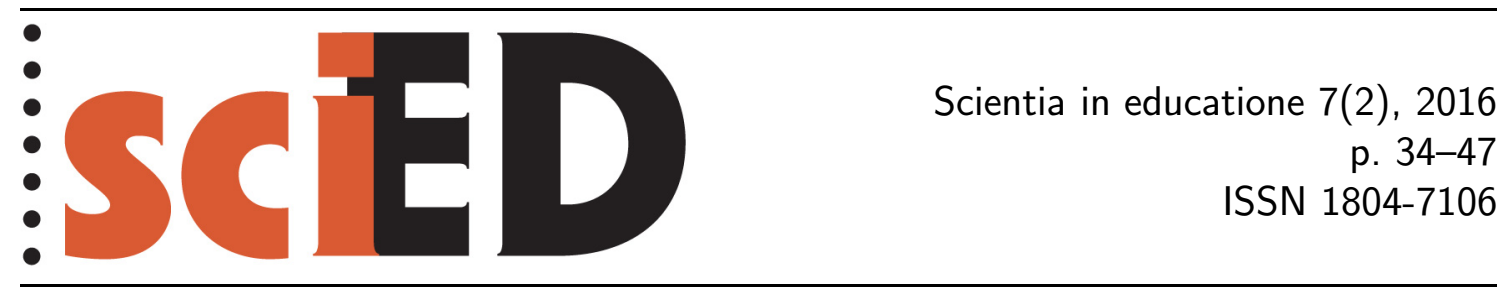

\title{
Obsahová analýza tématu evoluce člověka v českých učebnicích dějepisu
}

\author{
Radka Marta Dvořáková, Karolína Absolonová
}

\begin{abstract}
Abstrakt
V této studii analyzujeme obsahovou správnost tématu evoluce člověka ve 14 českých dějepisných učebnicích. Zaměřujeme se na tři klíčové oblasti - pojetí vývoje člověka, druhovou analýzu a pojetí druhu $H$. sapiens. Upozorňujeme na řadu zastaralých informací a opakujících se nepřesností, které učebnice dějepisu obsahují, jako je kupříkladu čistě lineární schéma evolučního vývoje nebo uvádění neandertálce jako poddruhu Homo sapiens. Upozorňujeme, jak a proč mohou tyto miskoncepce později komplikovat relevantní pochopení evoluce ve výuce přrírodopisu a biologie.
\end{abstract}

Klíčová slova: evoluce člověka, učebnice dějepisu, obsahová analýza.

\section{Content Analysis of Czech School History Textbook with regard to Human Evolution Topics}

\begin{abstract}
Our study analysed the factual accuracy of the issue of human evolution as presented in fourteen Czech history textbooks . We focused upon three key fields - the concept of human evolution, species analysis and the conception of $H$. sapiens. We point out the fact that the history textbooks contain multiple outdated information and mistakes, such as the linear image of evolution or the persistent labeling of $H$. neaderthalensis as a subspecies of $H$. sapiens. We draw attention to some ways in which this misconception is likely to complicate the students' understanding of evolution in the during subsequent science lessons.
\end{abstract}

Key words: human evolution, history textbooks, content analysis. 


\section{1 ÚvOD}

Učebnice jsou jednou ze základních učebních pomůcek. Přestože nepatří mezi závazné výukové dokumenty, nezanedbatelnou měrou formují na všech stupních vzdělávání fakta, která jsou do výuky zařazována (Driscoll et al., 1994; Mikk, 2007). Někteří autoři uvádějí, že učitelé vycházejí při přípravě až $90 \%$ času vyučovací jednotky právě z učebnic (Woodward, 1986). Největší měrou to platí pro témata, v nichž se učitelé necítí úplně jisti - at už proto, že nenacházejí čas sledovat nejnovější poznatky a trendy v dynamicky se rozvíjejících disciplínách, nebo proto, že u kontroverznějších témat hledají v učebnici oporu, jejímiž stanovisky a tezemi se mohou zaštítit.

Učebnice lze analyzovat z mnoha hledisek. Obsah a jeho odborná správnost, zahrnující také prezentaci poznatků na současné úrovni vědy, na které cílí tato studie, je pouze jedním z řady aspektů. Vědecká správnost by měla být samozřejmostí Altmann (1975: s. 193-199) klade didaktickou zásadu vědeckosti, v kontextu výuky biologie na všech stupních škol, na první místo; i při hodnocení učebnic obecně se jedná o jedno z nejdůležitějších kritérií (Sikorová, 2007). Průcha (1998: s. 80) uvádí, že ve složce obsahu učebnic nebývají spatřovány závažné problémy a že př́padné rozpory se týkají spíše výběru učiva, nebot odborníci na určitý vyučovací předmět se mohou odlišovat $\mathrm{v}$ názorech na to, co z určité vědy do učiva začlenit a co ne. Podle našich zkušeností se ovšem ukazuje, že ne vždy je požadavek odborné správnosti naplňován. Aktuální poznatky nebo koncepty, s nimiž odborná správnost prezentovaných informací těsně souvisí, se dostávají do učebnic až s určitým odstupem (Alles et Stevenson, 2003; DeSilva, 2004). Děje se to mimo jiné i proto, že autoři nebo recenzenti učebnic často stojí před obtížným úkolem odhadnout, nakolik jsou některé nové objevy relevantní a zda nebudou v dohledné době opět zrevidovány. Snaha nevybočit z řady a držet se starých osvědčených schémat a informací se jim pak často může zdát nejjistějším řešením (Quesssada et al., 2008; Padian, 2013).

Tato studie se zaměřuje na téma vzniku a vývoje člověka, které má značný mezipředmětový a mezioborový potenciál. Naším hlavním cílem byla analýza aktuálnosti a odborné správnosti prezentovaných údajů o evoluci člověka v aktuálně používaných českých učebnicích dějepisu. Studie dále otevírá diskuzi, jak informace předkládané v jednom předmětu (dějepise) mohou ovlivnit znalosti nebo chápání souvislostí při výuce obdobného tématu v předmětu jiném (přírodopise/biologii).

\section{ZaKOTVENÍ TÉMATU V RÁMCOVÝCH VZDĚLÁVACÍCH PROGRAMECH A JEHO VÝUKA NA ZÁKLADNÍCH A STŘEDNÍCH ŠKOLÁCH}

Úsvit lidských dějin, zahrnující vznik a vývoj člověka v pravěku, je pevnou součástí Rámcových vzdělávacích programů pro základní vzdělávání (RVP ZV, 2010) i vzdělávání gymnaziální (RVP G, 2007) ve vzdělávacím oboru dějepis (RVP ZV, 2010: s. 59; RVP G, 2007: s. 43) a také př́rodopis (RVP ZV, 2010: s. 45), resp. biologie (RVP G, 2007: s. 33). Výuka tohoto tématu v dějepise tradičně předchází výuce tématu v přírodních vědách, a to jak na 2 ., tak na 3 . stupni vzdělávání. V dějepise se s látkou žáci zpravidla setkávají hned v jedné z prvních hodin v šesté třídě (primě) na 2. stupni a v prvním ročníku (kvintě) na 3. stupni v rámci nejstaršího údobí dějin, dějin pravěku, což odráží i zařazení tématu v učebnicových řadách. Na školách, podle 
našich zkušeností, zpravidla nedochází k cílenému propojování informací předkládaných učiteli humanitních a př́rodovědných oborů, přesto nelze podceňovat skutečnost, že informace a myšlenková schémata, která si o tématu odnáší žáci z učebnic a hodin dějepisu, utváří vědomostní základ, se kterým posléze přicházejí do hodin př́rodopisu a biologie, kdy se téma v rámci školní docházky otevírá podruhé.

\section{MetOdIKA VÝZKUMU}

Předmětem studie byla kvalitativní obsahová analýza, zaměřená na vědeckou správnost a s ní související aktuálnost informací tématu vznik a vývoj člověka v aktuálně používaných českých učebnicích dějepisu. Analyzovaly jsme celkem 14 učebnic 8 určených pro výuku na 2 . stupni a 6 pro výuku na 3 . stupni. 12 ze 14 analyzovaných učebnic obsahovalo doložku MŠMT, která by měla být garancí jejich celkové kvality. Přehled analyzovaných učebnic zachycuje tabulka 1. Pracovaly jsme s nejnovějšími dostupnými vydáními učebnic (revize nebo nové texty vydané od roku 2000 dále), ačkoli v praxi na školách se často využívají i vydání starší. Z tohoto důvodu jsme do souboru zařadily také jednu učebnici z roku 1999 (Michovský, 1999), která je podle našich zjištění některými učiteli také používána.

Tab. 1: Přehled analyzovaných učebnic dějepisu (učebnice jsou seskupeny podle stupně vzdělávání, pro který jsou určeny, v rámci obou skupin jsou seřazeny vzestupně podle roku vydání)

\begin{tabular}{|c|c|c|c|c|c|}
\hline název učebnice & autor & nakladatelství & rok & stupeň & $\begin{array}{l}\text { doložka } \\
\text { MŠMT }\end{array}$ \\
\hline Dějepis I. díl & Michovský & SPL práce/Albra & 1999 & 2. & ano \\
\hline $\begin{array}{l}\text { Dějiny pravěku } \\
\text { a starověkého } \\
\text { orientu }\end{array}$ & Augusta, Honzák & SPL práce/Albra & 2000 & 2. & ano \\
\hline Pravěk a starověk & $\begin{array}{l}\text { Augusta, Honzák, } \\
\text { Hirschová }\end{array}$ & SPL práce/Albra & 2008 & 2. & ano \\
\hline $\begin{array}{l}\text { Dějiny pravěku } \\
\text { a starověku }\end{array}$ & $\begin{array}{l}\text { Mandelová, } \\
\text { Kunstová, Pařízková }\end{array}$ & Dialog & 2009 & 2. & ano \\
\hline $\begin{array}{l}\text { Dějepis } 6 \text { Pravěk } \\
\text { a starověk }\end{array}$ & Koucká & Prodos & 2009 & 2. & ano \\
\hline Dějepis 6 & $\begin{array}{l}\text { kol. (kap. Pravěk: } \\
\text { Popelka, Kalistová, } \\
\text { Soukup) }\end{array}$ & Fraus & 2013 & 2. & ano \\
\hline $\begin{array}{l}\text { Dějepis, pravěk } \\
\text { a starověk }\end{array}$ & $\begin{array}{l}\text { Bednaříková, } \\
\text { Kysučan, Fejfušová }\end{array}$ & Nová škola & 2015 & 2. & ano \\
\hline Dějepis 6 & Válková & $\mathrm{SPN}$ & 2015 & 2. & ano \\
\hline Dějepis pro SOŠ & Čapek, Pátek & Scientia & 2001 & 3. & ano \\
\hline $\begin{array}{l}\text { Dějepis } 1 \text { pravěk } \\
\text { a starověk }\end{array}$ & Popelka, Válková & $\mathrm{SPN}$ & 2008 & 3. & ne \\
\hline $\begin{array}{l}\text { Dějepis pro SOŠ } \\
1+2\end{array}$ & Beneš, Nálevka & SPL práce/Albra & 2009 & 3. & ano \\
\hline Dějepis pro SOŠ & $\begin{array}{l}\text { Čornej, Čornejová, } \\
\text { Parkan, Kudrys }\end{array}$ & SPN & 2010 & 3. & ano \\
\hline $\begin{array}{l}\text { Dějiny pravěku } \\
\text { a starověku }\end{array}$ & Souček & SPL práce/Albra & 2010 & 3. & ano \\
\hline Dějepis na dlani & $\begin{array}{l}\text { Kohoutková, } \\
\text { Komsová }\end{array}$ & Rubico & 2014 & 3. & ne \\
\hline
\end{tabular}


V učebnicích byly sledovány a hodnoceny vytipované klíčové oblasti tématu vznik a vývoj člověka, konkrétně:

1. pojetí evolučního vývoje člověka,

2. druhové spektrum,

3. pojetí našeho druhu ve vztahu ke zbytku živé př́írody.

Hledaly jsme odpovědi na následující výzkumné otázky:

Ad 1) Jak autoři učebnic pojímají a prezentují evoluční vývoj člověka?

Sledované kategorie: pojetí a znázornění vývoje člověka (lineární řada vs. fylogenetický strom). Zajímalo nás, zda učebnice prezentují evoluční vývoj člověka jako čistě lineární posloupnost, kdy jeden druh přechází postupně v jiný, nebo reflektují, že některé druhy existovaly $\mathrm{v}$ evolučním čase na Zemi vedle sebe a také, že často nelze s našimi dosavadními znalostmi jednoznačně tvrdit, který druh je nebo není př́mým předchůdcem druhu jiného. Za zastaralé a chybné pojetí jsme považovaly situaci, kdy autoři učebnice prezentovali, že konkrétní druh přechází postupně v jiný, přičemž geologický záznam naopak ukazuje, že druhy koexistovaly na planetě Zemi nějakou dobu vedle sebe. Za ne zcela přesné pojetí evoluce člověka jsme považovaly situaci, kdy autoři sice z lineárního schématu evoluce člověka vycházeli, ale explicitně nepopisovali přerod jednoho druhu v jiný a v některých případech i reflektovali, že některé druhy homininů existovaly v evolučním čase na Zemi vedle sebe. Sledovaly jsme také, jestli učebnice vývoj člověka prezentují i graficky - časovou osou, souhrnnou tabulkou nebo obrázkovou vývojovou řadou či ho jen popisují a komentují slovně.

Ad 2) Kolik druhů homininů, př́ipadně dalších druhů fosilních primátů, jednotlivé učebnice prezentují a o které druhy konkrétně se jedná? Z jaké doby pocházejí nejnovější paleoantropologické nálezy, které učebnice prezentují? Jaké české ekvivalenty latinských názvů učebnice používají? Obsahují charakteristiky druhů faktické chyby, nepřesnosti nebo zastaralé informace?

Sledované kategorie: druhy homininů - jejich počet v jednotlivých učebnicích a druhové spektrum, české ekvivalenty latinských názvů, faktická správnost charakteristik jednotlivých druhů. Zajímalo nás, kolik druhů homininů (tedy všech vymřelých i žijících druhů v linii od posledního společného předka lidí a šimpanzů k modernímu člověku), případně dalších fosilních primátů, jednotlivé učebnice prezentují. Sledovaly jsme i druhové spektrum a dále, které nejnovější objevy druhů pronikly do dějepisných učebnic. Srovnávaly jsme, zda aktuální české učebnice dějepisu používají jednotné české názvosloví druhů a zda obsahují charakteristiky prezentovaných druhů faktické chyby, nepřesnosti nebo zastaralé informace. V analyzovaných textech jsme se zaměřily také na odlišení fakt, která máme skutečně (např. archeologicky) podložena, a představ, která v některých učebnicích jako fakta prezentována jsou, ale jedná se pouze o domněnky a dohady. Informace a závěry prezentované v učebnicích jsme srovnávaly s aktuálními poznatky a stanovisky, akceptovanými v moderní paleoantropologii. Vycházely jsme z nejnovějších českých monografií (Svoboda, 2014; Soukup, 2015) a aktuálních vědeckých článků (viz seznam použité literatury).

Ad 3) Jak chápou učebnice dějepisu druh Homo sapiens ve vztahu ke zbytku živé př́rody?

Sledované kategorie: pojetí druhu Homo sapiens. Zajímalo nás, zda autoři dějepisných učebnic prezentují náš vlastní druh jako nejdokonalejší evoluční stupeň „korunu stvoření“, jako entitu kvalitativně odlišnou od ostatních živých tvorů (což je přístup charakteristický spíše pro oblast humanitních věd) nebo jako „součást přírody" (což je typičtější pro oblast přírodních věd). 


\section{VÝSLEDKY}

\subsection{POJETí VÝVOJE ČLOVĚKA}

Většina analyzovaných dějepisných učebnic (přehled viz tab. 2) prezentuje evoluci člověka jako čistě lineární proces, v němž jeden druh lidských předchůdců postupně přechází v jiný. Učebnice pro základní školy podtrhují toto zastaralé lineární schéma

Tab. 2: Pojetí a forma prezentace tématu vývoje člověka v učebnicích dějepisu

\begin{tabular}{|c|c|c|}
\hline $\begin{array}{l}\text { Název učebnice } \\
\text { nakladatelství, rok, (stupeň) }\end{array}$ & $\begin{array}{l}\text { Pojetí tématu, } \\
\text { komentář }\end{array}$ & $\begin{array}{l}\text { Forma prezentace } \\
\text { tématu }\end{array}$ \\
\hline Dějepis I. díl & zastaralé a chybné, & slovní popis \\
\hline SPL práce/Albra, 1999, (2.) & čistě lineární posloupnost druhů & $\begin{array}{l}\text { časová osa } \\
\text { souhrnná tabulka }\end{array}$ \\
\hline $\begin{array}{l}\text { Dějiny pravěku } \\
\text { a starověkého orientu } \\
\text { SPL práce/Albra, 2000, (2.) }\end{array}$ & $\begin{array}{l}\text { zastaralé a chybné, } \\
\text { čistě lineární posloupnost druhů }\end{array}$ & $\begin{array}{l}\text { slovní popis } \\
\text { obr. vývojová řada }\end{array}$ \\
\hline $\begin{array}{l}\text { Pravěk a starověk } \\
\text { SPL práce/Albra, 2008, (2.) }\end{array}$ & $\begin{array}{l}\text { ne zcela přsesné, } \\
\text { text evokuje lineální pojetí + zmínku } \\
\text { o slepé větvi vývoje neandertálcích }\end{array}$ & slovní popis \\
\hline $\begin{array}{l}\text { Dějiny pravěku } \\
\text { a starověku } \\
\text { Dialog, 2009, (2.) }\end{array}$ & $\begin{array}{l}\text { ne zcela přesné, } \\
\text { osa a vývojová řada evokují lineální } \\
\text { pojetí + zmínka, že vývoj byl } \\
\text { složitější }\end{array}$ & $\begin{array}{l}\text { slovní popis } \\
\text { časová osa } \\
\text { obr. vývojová } \\
\text { řada }\end{array}$ \\
\hline $\begin{array}{l}\text { Dějepis } 6 \text { Pravěk } \\
\text { a starověk } \\
\text { Prodos, } 2009,(2 .)\end{array}$ & $\begin{array}{l}\text { zastaralé a chybné, } \\
\text { čistě lineární posloupnost druhů }\end{array}$ & $\begin{array}{l}\text { slovní popis } \\
\text { obr. vývojová } \\
\text { řada }\end{array}$ \\
\hline Dějepis 6 & $\mathrm{OK}$ & slovní popis \\
\hline Fraus, 2013, (2.) & $\begin{array}{l}\text { datace druhů na ose na sebe plynule } \\
\text { nenavazuje }\end{array}$ & časová osa \\
\hline $\begin{array}{l}\text { Dějepis, pravěk } \\
\text { a starověk }\end{array}$ & $\begin{array}{l}\text { zastaralé a chybné, } \\
\text { čistě lineární posloupnost }\end{array}$ & $\begin{array}{l}\text { slovní popis } \\
\text { časová osa }\end{array}$ \\
\hline Nová škola, 2015, (2.) & $\begin{array}{l}\text { druhů + zmínka o slepé větvi vývoje } \\
\text { neandertálcích }\end{array}$ & $\begin{array}{l}\text { obr. vývojová } \\
\text { řada }\end{array}$ \\
\hline $\begin{array}{l}\text { Dějepis } 6 \\
\text { SPN, 2015, (2.) }\end{array}$ & $\begin{array}{l}\text { ne zcela přesné, } \\
\text { text evokuje lineální pojetí + zmínku } \\
\text { o slepé větvi vývoje neandertálcích }\end{array}$ & slovní popis \\
\hline $\begin{array}{l}\text { Dějepis pro SOŠ } \\
\text { Scientia, } 2001,(3 .)\end{array}$ & $\begin{array}{l}\text { zastaralé a chybné, } \\
\text { čistě lineární posloupnost druhů }\end{array}$ & slovní popis \\
\hline $\begin{array}{l}\text { Dějepis } 1 \text { pravěk } \\
\text { a starověk }\end{array}$ & $\begin{array}{l}\text { zastaralé a chybné, } \\
\text { lineární posloupnost druhů + chybný }\end{array}$ & $\begin{array}{l}\text { slovní popis } \\
\text { vývojové schéma }\end{array}$ \\
\hline SPN, 2008, (3.) & fylogenenetický strom & \\
\hline $\begin{array}{l}\text { Dějepis pro SOŠ } \mathbf{1}+\mathbf{2} \\
\text { SPL práce/Albra, 2009, (3.) }\end{array}$ & $\begin{array}{l}\text { nelze určit, } \\
\text { pouze zmínka o vzniku rodu Homo }\end{array}$ & slovní popis \\
\hline Dějepis pro SOŠ & zastaralé a chybné, & slovní popis \\
\hline SPN, 2010, (3.) & $\begin{array}{l}\text { lineární posloupnost druhů }+ \text { chybný } \\
\text { fylogenenetický strom }\end{array}$ & vývojové schéma \\
\hline $\begin{array}{l}\text { Dějiny pravěku } \\
\text { a starověku } \\
\text { SPL práce/Albra, 2010, (3.) } \\
\text { Dějepis na dlani } \\
\text { Rubico, 2014, (3.) }\end{array}$ & $\begin{array}{l}\text { zastaralé a chybné, } \\
\text { čistě lineární posloupnost } \\
\text { druhů + zmínka o australopitécích } \\
\text { zastaralé a chybné, } \\
\text { čistě lineární posloupnost druhů }\end{array}$ & $\begin{array}{l}\text { slovní popis } \\
\text { vývojová řada } \\
\text { lebek } \\
\text { slovní popis }\end{array}$ \\
\hline
\end{tabular}


často i graficky - časovou osou nebo obrázkovou vývojovou řadou, která zachycuje postupný vývoj znaků (postupné zvětšování mozkovny a bradového výběžku, mizení nadočnicových oblouků, napřimování nahrbené postavy atd.). Pouze jediná z učebnic pro základní školy, titul Dějepis 6 nakladatelství Fraus (Popelka et al., 2013: s. 16), uvádí u jednotlivých druhů na časové ose dataci, která na sebe plynně nenavazuje, ale překrývá se, a čistě lineární schéma tak nějakým způsobem narušuje. Učebnice Dějiny pravěku a starověku nakladatelství Dialog (Mandelová et al., 2009: s. 8) zase připojuje k obrázku časové osy poznámku v závorce, že jsou „uvedeny pouze hlavní druhy, vývoj byl složitější a uvádějí se různá datování".

Ze středoškolských učebnic pouze titul Dějiny pravěku a starověku nakladatelství SPL práce/Albra (Souček, 2010: s. 9) zmiňuje nad rámec čistě lineárního schématu, že australopitékové a Homo habilis žili v Africe po dlouhou dobu společně, nicméně prezentované druhy rodu Homo (H. habilis, H. erectus, H. sapiens) již splývají v jednu za sebou jdoucí řadu.

Další dvě středoškolské učebnice - Dějepis 1 pravěk a starověk (Popelka \& Válková, 2008: s. 13) a Dějepis pro $S O \breve{S}$ (Čornej et al., 2010: s. 7), obě vydané SPN, obsahují tentýž obrázek fylogenetického stromu nadčeledi Hominoidea, který zachycuje kromě moderního člověka i další recentní lidoopy a již vymřelé druhy jejich předků a předchůdců. Linie tohoto schématu vedoucí $\mathrm{k}$ moderním lidem ovšem „klasické“ lineární schéma „H. habilis $-H$. erectus - H. sapiens" opět obsahuje, což podtrhává i doprovodný text učebnice. Zobrazený fylogenetický strom navíc nebere v potaz poznatky moderní genetiky o vzájemné př́buznosti moderních lidoopů - jako nejbližšího recentního příbuzného šimpanze uvádí gorilu, nikoli člověka (srov. Barton et al., 2007: s. 728-730; Storch et al., 2013: s. 434-435; Soukup, 2015: s. 181). Dějepis pro SOŠ $1+2$, nakladatelství SPL práce/Albra (Beneš \& Nálevka, 2009: s. 7) zmiňuje pouze vznik rodu Homo před 2,5 miliony let a dále informaci nerozvádí.

Jako př́nos u některých hodnocených dějepisných učebnic zmiňujeme fakt, že pojednávají i o střídání dob ledových a meziledových a s tím souvisejících změnách krajiny, fauny a flóry (Michovský, 1999: s. 12-13; Koucká, 2000: s. 11; Augusta et al., 2008: s. 11; Popelka \& Válková, 2008: s. 15; Popelka et al., 2013: s. 20). Tato informace je důležitá pro pochopení jednoho z hlavních hnacích motorů lidského kulturního vývoje, zejména v Evropě a Asii.

\subsection{DRUhové SPEKTRUM}

Zaměříme-li se na druhovou skladbu (přehled viz tab. 3), učebnice pro ZŠ zmiňují 3-7 druhů, přičemž některé druhy jsou opravdu jen letmo zmíněny v mapce či schématu a v textu se píše především o člověku zručném (Homo habilis), člověku vzpřímeném (Homo erectus) a našem vlastním druhu (Homo sapiens).

Středoškolské učebnice jsou v počtu druhů mnohem variabilnější: od pouhé zmínky rodu Homo a absence jakýchkoli dalších informací o konkrétních druzích v učebnici Dějepis pro $S O \breve{S} 1+2$ nakladatelství SPL práce/Albra, až po 14 různých druhů, zahrnujících i společné prapředky lidí a moderních lidoopů, zmíněných v titulu Dějepis pro SOS̆ a také Dějepis 1 pravěk a starověk, vydaných SPN.

Nejnovější paleoantropologické nálezy, které se v učebnicích dějepisu objevují, spadají do 60.-70. let 20. století, viz např. zmínka o druhu Homo rudolfensis v učebnici Dějepis 6 nakladatelství Fraus (Popelka et al., 2013: s. 16; srov. Leakey 1973). Novější nálezy, např. rodů Ardipithecus, Sahelanthropus, Orrorin nebo druhů např. Homo floresiensis, žádná z analyzovaných dějepisných učebnic neobsahuje. 
Tab. 3: Přehled druhů uvedených v učebnicích dějepisu

\begin{tabular}{|c|c|c|}
\hline $\begin{array}{l}\text { Název učebnice } \\
\text { nakladatelství, rok, (stupeň) }\end{array}$ & $\begin{array}{l}\text { Počet } \\
\text { druhů }\end{array}$ & Výčet druhů \\
\hline $\begin{array}{l}\text { Dějepis I. díl } \\
\text { SPL práce/Albra, 1999, (2.) }\end{array}$ & 3 & $\begin{array}{l}\text { H. habilis, H. erectus, H. sapiens }(+H . \text { sapiens } \\
\text { sapiens) }\end{array}$ \\
\hline $\begin{array}{l}\text { Dějiny pravěku } \\
\text { a starověkého orientu } \\
\text { SPL práce/Albra, 2000, (2.) }\end{array}$ & 6 & $\begin{array}{l}\text { H. habilis, H. erectus, } H . \text { neanderthalensis, } \\
\text { H. sapiens }(+H . \text { sapiens sapiens }) \\
\text { Australopithecus, Dryopithecus }\end{array}$ \\
\hline $\begin{array}{l}\text { Pravěk a starověk } \\
\text { SPL práce/Albra, 2008, (2.) }\end{array}$ & 4 & $\begin{array}{l}\text { H. habilis, H. erectus, H. neanderthalensis, } \\
\text { H. sapiens }(+H . \text { sapiens sapiens })\end{array}$ \\
\hline $\begin{array}{l}\text { Dějiny pravěku } \\
\text { a starověku } \\
\text { Dialog, 2009, (2.) }\end{array}$ & 7 & $\begin{array}{l}\text { H. habilis, H. erectus, H. heidelbergnsis, } \\
\text { H. steinheimenensis, H. neanderthalensis, } \\
\text { H. sapiens }(+H . \text { sapiens sapiens }), \\
\text { Australopithecus }\end{array}$ \\
\hline $\begin{array}{l}\text { Dějepis } 6 \text { Pravěk } \\
\text { a starověk } \\
\text { Prodos, } 2009,(2 .)\end{array}$ & 4 & $\begin{array}{l}\text { H. habilis, H. erectus, H. neanderthalensis, } \\
\text { H. sapiens }(+H . \text { sapiens sapiens })\end{array}$ \\
\hline $\begin{array}{l}\text { Dějepis } 6 \\
\text { Fraus, } 2013,(2 .)\end{array}$ & 6 & $\begin{array}{l}\text { H. habilis, H. rudolfensis, H. ergaster, } \\
\text { H. heidelbergensis, H. neanderthalensis, } \\
\text { H. sapiens }\end{array}$ \\
\hline $\begin{array}{l}\text { Dějepis, pravěk } \\
\text { a starověk } \\
\text { Nová škola, 2015, (2.) }\end{array}$ & 5 & $\begin{array}{l}\text { H. habilis, H. erectus, H. neanderthalensis, } \\
\text { H. sapiens }(+H . \text { sapiens sapiens }), \\
\text { Australopithecus }\end{array}$ \\
\hline $\begin{array}{l}\text { Dějepis } 6 \\
\text { SPN, } 2015,(2 .)\end{array}$ & 3 & H. habilis, H. neanderthalensis, H. sapiens \\
\hline $\begin{array}{l}\text { Dějepis pro SOŠ } \\
\text { Scientia, } 2001,(3 .)\end{array}$ & 1 & H. sapiens (H. sapiens sapiens) \\
\hline $\begin{array}{l}\text { Dějepis } 1 \text { pravěk } \\
\text { a starověk } \\
\text { SPN, 2008, (3.) }\end{array}$ & 14 & $\begin{array}{l}\text { H. habilis, H. erectus, H. neanderthalensis, } \\
\text { H. sapiens }(+H . \text { sapiens sapiens }), \text { A. africanus, } \\
\text { A. afarensis, A. robustus, A. boisei, } \\
\text { A. crassidens, Dryopithecus, Aegyptopithecus, } \\
\text { Kenyapithecus, Ramapithecus, Proconsul }\end{array}$ \\
\hline $\begin{array}{l}\text { Dějepis pro SOŠ } \mathbf{1 + 2} \\
\text { SPL práce/Albra, 2009, (3.) }\end{array}$ & 0 & pouze rod Homo \\
\hline $\begin{array}{l}\text { Dějepis pro SOŠ } \\
\text { SPN, } 2010,(3 .)\end{array}$ & 14 & $\begin{array}{l}\text { H. habilis, H. erectus, H. neanderthalensis, } \\
\text { H. sapiens }(+\dot{H} . \text { sapiens sapiens }) \text {, A. africanus, } \\
\text { A. afarensis, A. robustus, A. boisei, } \\
\text { A. crassidens, Dryopithecus, Aegyptopithecus, } \\
\text { Kenyapithecus, Ramapithecus, Proconsul }\end{array}$ \\
\hline $\begin{array}{l}\text { Dějiny pravěku } \\
\text { a starověku } \\
\text { SPL práce/Albra, 2010, (3.) }\end{array}$ & 5 & $\begin{array}{l}\text { H. habilis, } H . \text { erectus, } H . \text { neanderthalensis, } \\
\text { H. sapiens }(+H . \text { sapiens sapiens }) \\
\text { Australopithecus }\end{array}$ \\
\hline $\begin{array}{l}\text { Dějepis na dlani } \\
\text { Rubico, } 2014,(3 .)\end{array}$ & 5 & $\begin{array}{l}H . \text { habilis, H. erectus, } H . \text { neanderthalensis, } \\
\text { H. steinheimenensis, } H . \text { sapiens }(+H . \text { sapiens } \\
\text { sapiens a } H . \text { sapiens palestinus })\end{array}$ \\
\hline
\end{tabular}


Označování některých druhů, zejména pokud jde o české názvosloví, je v českých učebnicích dějepisu značně nejednotné. Homo habilis bývá nejčastěji překládán jako člověk zručný, ale můžeme se setkat i s překladem člověk schopný (Koucká, 2009: s. 11; Mandelová et al., 2009: s. 10) anebo pračlověk (Válková, 2015: s. 22). Termínem pračlověk ovšem označují jiné učebnice dějepisu archaickou formu Homo sapiens (Augusta \& Honzák, 2000: s. 16; Augusta et al., 2008: s. 12). Náš vlastní druh pojmenovávají učebnice dále jako člověka dnešního typu, člověka našeho typu, člověka rozumného nebo anatomicky moderního člověka.

Velmi rozššřrenou nepřesností, která se objevuje ve většině dějepisných učebnic (přehled viz tab. 3), je uvádění „druhu“ Homo sapiens sapiens jako dalšího evolučního stupně, který se vyvíjí z druhu Homo sapiens před cca 40000 lety. Lineární schéma Homo habilis - Homo erectus - Homo sapiens - Homo sapiens sapiens se objevuje ve 4 ze 6 analyzovaných středoškolských učebnic a v 6 z 8 učebnic pro základní školy.

Neandertálci, pokud je učebnice zmiňují, jsou v souladu s dnešními poznatky prezentováni již většinou jako slepá vývojová větev, jen titul Dějiny pravěku a starověku nakladatelství Dialog (Mandelová et al., 2009: s. 11) o nich ještě hovoří jako o předcích a předchůdcích dnešních Evropanů a učebnice Dějepis 1 Pravěk a starověk vydaná SPN (Popelka \& Válková, 2008: s. 14) o nich píše jako o bezprostředních předchůdcích člověka dnešního typu a variantě současného člověka. Neandertálci (Homo neanderthalensis) jsou ve všech 4 středoškolských učebnicích, kde je o nich zmínka, nesprávně označováni za variantu či poddruh Homo sapiens. Učebnice pro základní školy jsou na tom o něco lépe - tuto zastaralou informaci uvádí pouze 2 z 6 učebnic, které neandertálce zmiňují (Mandelová et al., 2009: s. 10; Bednaříková et al., 2015: s. 14).

Popisy jednotlivých druhů člověka a jejich životního stylu jsou v učebnicích často velmi schematické, stručné a poplatné lineární časové ose. Nápadné je to zejména u datace, která se v extrémním př́ipadě liší od vědeckého úzu z doby vydání učebnice téměř o milion let, viz např. datace druhu Homo habilis v titulu Dějepis I. díl nakladatelství SPL práce/Albra (Michovský, 1999: s. 12). Problematické datování můžeme nalézt např. i u popisu jeskynních maleb, kde autoři zcela pomíjejí objev a datování jeskyně Chauvet ve Francii (Augusta et al., 2008; Popelka \& Válková, 2008; Mandelová et al., 2009; Souček, 2010; Válková, 2015). Problematické je také uvádění datování pravěku ve formě př. n. l., ačkoli v odborné literatuře je běžnější datování před současností (BP - Before Present). Je pochopitelné, že vzhledem k následujícím historickým obdobím volí autoři tuto formu datace, nebylo by však na škodu žáky s běžnějším paleoantropologickým datováním alespoň seznámit.

Někdy v učebnicích najdeme i vyslovené chyby. Můžeme se např. dočíst, že Homo sapiens se před 25000 lety rozššřril do Austrálie (Popelka \& Válková, 2008: s. 14; Čornej et al., 2010: s. 7) - to je zhruba polovina běžně uváděné datace (srov. Pertaglia et al., 2010; Svoboda, 2014: s. 346) a dále se chybně uvádí, že lidé se do Austrálie dostali přes pevninské mosty (Michovský, 1999: s. 22; Popelka et Válková, 2008: s. 14; srov. Svoboda, 2014: s. 346). Nepřesnou dataci osídlení Austrálie uvádí i další učebnice, které ji datují ke konci poslední doby ledové (Michovský, 1999: s. 22; Koucká, 2009: s. 15).

Dalšími zavádějícími informacemi jsou tvrzení o místě vzniku našeho druhu. $\mathrm{V}$ některých učebnicích dějepisu se lze dočíst, že za místo vzniku Homo sapiens sapiens se považuje oblast mezi střední Evropou a jihozápadní Asií (Popelka \& Válková, 2008: s. 14) a že člověk dnešního typu se vyvinul ze svých primitivnějších prapředků paralelně v Africe, Asii a Evropě (Michovský, 1999: s. 19; Koucká, 2009: 
s. 15; Válková, 2015: s. 22) nebo pouze v Evropě (Mandelová et al., 2009: s. 13) či v oblasti Středozemního moře (Augusta \& Honzák, 2000: s. 16). Za oblast vzniku druhu Homo sapiens je však v moderní paleoantropologii považována jednoznačně Afrika (napr. Svoboda, 2014: s. 342). Tuto informaci ovšem explicitně uvádí pouze 2 ze 14 analyzovaných učebnic (Popelka et al., 2013: s. 16; Bednaříková et al., 2015: s. 15).

Charakteristiky popisovaných druhů také často obsahují informace, které jsou předkládány jako fakta, ačkoli je nelze v paleolitu archeologicky doložit a pouze se domníváme, že tomu tak mohlo být, jako např. uctívání žen jako symbolu plodnosti, uctívání předků a duchů, představy o lidské duši nebo život v rodových tlupách. $\mathrm{Na}$ tuto skutečnost by však měli být studenti v textu učebnice upozorněni.

\subsection{PoJetí NAŠEHO DRUHU VE VZTAHU Ke ZBYTKU ŽIVÉ PŘ́́RODY}

Postavení našeho druhu ve vztahu ke zbytku živé přírody zmiňuje explicitně 9 ze 14 analyzovaných učebnic. Pouze 2 učebnice prezentují druh Homo sapiens jako jeden z mnoha živočišných druhů. V ZŠ učebnici Dějepis I. díl, nakladatelství SPL práce/Albra se píše: „Člověk jako živočich je součástí živé přírody a vyvinul se v ní jako samostatný rod." (Michovský, 1999: s. 12). SŠ učebnice Dějiny pravěku a starověku nakladatelství SPL práce/Albra (Souček, 2010: s. 9) obsahuje tabulku, která zachycuje člověka jako druh v zoologické klasifikaci.

Ostatní učebnice dějepisu vyčleňují člověka z přírody jako mimořádnou, kvalitativně odlišnou entitu; poukazují přitom především na kulturní a sociální rysy, které nemají často u živočichů relevantní obdobu, cit.: „Vznik člověka je tedy výsledkem kulturního a sociálního vývoje, který spolu s dalšími vlivy vytvořil předpoklady výjimečného postavení člověka v živé př́rodě.“ (Čapek \& Pátek, 2001: s. 12), dále např.: „Nejen, že své blízké pohřbívají, ale do hrobů jim vkládají i různé užitečné či ozdobné předměty. Můžeme se tedy domnívat, že již měli své představy o posmrtném životě. . S Snad právě v této chvíli se mění z ,nejchytřejšího zviřrete (Augusta et al., 2008: s. 12). A dále často chápou člověka jako evoluční „vrchol stvořeni“", cit.: „Vznik člověka představuje poslední stupeň ve vývoji živé př́rody na naší planetě Zemi." (Čapek \& Pátek, 2001: s. 11).

\section{DisKuZE}

Pojetí vývoje člověka je v českých učebnicích dějepisu, zejména středoškolských, většinou dosti stručné a vzhledem $\mathrm{k}$ celkovému rozsahu učebnice se tomuto tématu obvykle věnuje malý počet stran; u středoškolských učebnic jsou to v průměru necelé 3 strany, což odpovídá necelému 1,5\% rozsahu učebnice, u učebnic pro základní školy je tématu v průměru věnováno 8 stran, tedy necelých $8 \%$ rozsahu. Jedná se přitom o téma poměrně náročné, především svojí interdisciplinaritou, protože spojuje poznatky z biologie a dějepisu, případně i geologie, paleontologie, archeologie, antropologie, zoologie, klimatologie apod. Z tohoto hlediska klade na autory učebnic, učitele a nakonec i žáky zvýšené nároky. Redukce dat, vyplývající z omezeného rozsahu, který tématu věnují autoři učebnic, tak může vést $\mathrm{k}$ neúplnému nebo nedostatečnému pochopení obrazu lidského vývoje. Jako velmi problematické vnímáme předkládané pojetí vývoje člověka jako striktně lineární řady s pozvolnou proměnou znaků, které je typické pro většinu dějepisných učebnic. Toto pojetí, které je nejen 
zastaralé, ale pro relevantní pochopení evoluce lidského rodu velmi zavádějící (DeSilva, 2004), patrně přetrvává kvůli tradičnímu způsobu výuky dějepisu, který je postaven na lineární posloupnosti událostí. Vykročit z tohoto paradigmatu uvažování může být pro humanitně orientované učitele dějepisu velmi obtížné. Pro adekvátní pochopení lidské evoluce je ale potřeba reflektovat, že z „opice“ se v průběhu věků nestával plynule člověk, ale že evoluční vývoj postupoval mozaikovitě a různé znaky se měnily různou rychlostí. A také že různé druhy homininů žily na planetě Zemi často vedle sebe ve stejném evolučním čase. Umělé lineární evoluční schéma navíc vede autory textů k dalším faktickým chybám, jako je např. zavádějící datace druhů, která se v extrémním případě liší od vědeckého úzu z doby vydání učebnice téměř o milion let (viz Michovský, 1999: s. 12).

Výčet druhů homininů bývá v učebnicích dějepisu omezen jen na některé vybrané druhy. Jsou to nejčastěji druhy rodu Homo - H. habilis, H. erectus, H. neanderthalensis, H. sapiens (a „druh" H. sapiens sapiens). Ostatní druhy, zejména objevené a popsané v posledních padesáti letech, nejsou zmíněny vůbec nebo jen okrajově, což považujeme vzhledem $\mathrm{k}$ situaci na poli paleoantropologie za nedostatečné (viz např. výčet druhů v publikaci Soukup, 2015 nebo Svoboda, 2014). Určitou výjimkou je učebnice Dějepis 6 nakladatelství Fraus (Popelka et al., 2013), která uvádí trochu jiné spektrum homininů než většina učebnic. Poněkud nezvykle sice působí vypuštění poměrně významného druhu Homo erectus a jeho nahrazení archaičtější africkou variantou Homo ergaster; zejména v situaci, kdy byla jako ilustrační obrázek připojena olejomalba jávského člověka od Zdeňka Buriana, tj. druh Homo erectus sensu stricto (Popelka et al.: s. 19). Kladně hodnotíme, že prezentované druhy netvoří umělou lineární řadu, což je pro celkové pochopení lidské evoluce mnohem důležitější než znalost, resp. zařazení konkrétních druhů.

Většina učebnic stále prezentuje neandertálce jako předky současného člověka a nebo je řadí k Homo sapiens jako jeho poddruh. Tento názor však není dnes již všeobecně přijímán (Márquez et al., 2014; Svoboda, 2014: s. 308).

Sjednotit by se v učebnicích mělo také názvosloví. České učebnice používají pro Homo sapiens různé termíny jako moderní člověk, člověk rozumný, člověk dnešního typu, člověk současného typu, člověk moderního typu, člověk moudrý apod. Studenty může tato nejednotnost mást. Proto navrhujeme používat pouze termíny Homo sapiens nebo (anatomicky) moderní člověk. Ještě větší zmatek vnáší do učebnic termín „pračlověk", který někteří autoři používají jako synonymum pro nejstarší formy Homo sapiens, zatímco jiní jím označují druh Homo habilis. Pro jiné druhy rodu Homo bychom doporučili držet se latinské terminologie, snad s výjimkou neandertálců, jejichž český název je i v laické společnosti hluboce zakořeněn.

Nedoporučujeme ani používání pojmu archaický Homo sapiens, který může být také zavádějící. Jeho nálezy jsou dnes často řazeny k jiným středopaleolitickým druhům, např. k Homo heidelbergensis, Homo antecessor nebo k neandertálcům (viz např. Vančata, 2005 versus Svoboda, 2014). Používání názvů archaický H. sapiens či časný $H$. sapiens již dnes není mezi vědci všeobecně přijímáno a je neopodstatněné i z taxonomického hlediska (Schwartz a Tattersall, 2010; Svoboda, 2014).

Velmi časté je v učebnicích vyčleňování Homo sapiens sapiens jako samostatného druhu a datování jeho vzniku na 40000 let BP (např. Popelka \& Válková, 2008). Datum 40000 let BP je však datem objevení mladého paleolitu v Evropě a s evolucí člověka jako takového již nesouvisí ve smyslu vzniku nového druhu člověka. Uvádění tohoto data vychází především z interpretace archeologických nálezů v Evropě, kde se v té době objevila exploze nových technologií, ozdob a umění (tzv. mladý paleolit). Avšak v Africe, odkud moderní člověk pochází, se stejné technologie a ar- 
tefakty objevily již ve středním paleolitu o několik desítek tisíc let dřive (McBrearty \& Brooks, 2000). Rozdělování anatomicky moderního člověka na dva „druhy“ Homo sapiens a Homo sapiens sapiens je proto zcela zbytečné a zavádějící a může vést žáky mj. k domněnce, že druh Homo sapiens již vyhynul. Např. Jiří Svobodave své knize Předkové - Evoluce člověka (Svoboda, 2014) uvádí pouze druh Homo sapiens (anatomicky moderní člověk) a jeho vznik datuje na 200000 let BP. Stejně tak velmi zdařilá populárně-naučná kniha Robertsonové Evoluce - př́běh člověka (Robertsonová, 2012) uvádí pouze jeden druh Homo sapiens a obdobnou dataci jako Svoboda. Proto navrhujeme používat pro moderního člověka pouze název Homo sapiens, datovat jej na 200000 let BP a dále jej nečlenit. Jen některé učebnice používají pouze termín Homo sapiens bez dalšího dělení na poddruhy (Popelka et al., 2013).

Uvádění chyb v učebnicích považujeme za nejzávažnější nedostatek, protože žáci si je snadno zafixují do paměti pro celý další život, případně jim budou kolidovat s pozdější výukou přírodopisu a biologie. Jako příklady můžeme uvést vznik Homo sapiens sapiens před 40000 lety v různých oblastech mimo Afriku, přimo na sebe navazující dataci druhů člověka vyvolávající dojem přímé vývojové řady, chybnou dataci osídlení Austrálie nebo tvrzení o přechodu člověka do Austrálie po pevninském mostě (např. Popelka \& Válková, 2008). Učebnice také často uvádějí fakta, která nelze v paleolitu archeologicky doložit, a o nichž se pouze domníváme, že tomu tak mohlo být, aniž by na to autoři studenty upozornili (život lidí v rodech, uctívání žen jako symbolu plodnosti, uctívání předků a duchů apod.). Závažná je také absence nových nálezů na poli paleoantropologie a s nimi spojených nových poznatků o životě pravěkého člověka (např. objev otisků textilu na tábořištích mladopaleolitických lovců v Dolních Věstonicích a Pavlově, blíže viz Svoboda, 1999).

Učebnice dějepisu by také neměly zapomínat na propojení kulturního vývoje člověka s vývojem biologickým, nebot oba jsou neodmyslitelně spjaty. Nelze totiž oddělovat biologickou a kulturní stránku vývoje člověka bez ochuzení skutečnosti a ztráty informací. Jak píše náš přední primatolog a antropolog Václav Vančata (2005: s. 65): „Člověk je druhem primátů s některými zcela unikátními vlastnostmi a musí být chápán přísně jako tvor biosociální, u něhož měla například kultura, at už materiální nebo sociální, vždy velký adaptivní význam." Vyzdvihovat význačné postavení člověka v rámci živé přírody může být, zejména $\mathrm{v}$ kulturním kontextu, do jisté míry pochopitelné. Pokud se ale př́liš upneme $\mathrm{k}$ představě, že člověk je evoluční „vrchol stvoření“, jak to některé učebnice dějepisu prezentují, může to vést $\mathrm{k}$ mylnému dojmu, že evoluce člověka či živočichů obecně již skončila a také, že objevení se H. sapiens je vlastně plánovanou a pomyslnou metou evolučního procesu, což není pravda (Quessada et al., 2008). Ceská republika se sice nemusí dlouhodobě potýkat se snahami vyřadit téma evoluce ze školních osnov, jako je tomu v některých jiných státech (Skoog, 2005; Plutzer \& Berkman, 2008; Graf, 2011), přesto je adekvátní výuka tohoto tématu v českých školách velmi důležitá a žádoucí. Jedná o téma, které nám napomáhá pochopit sebe sama a kriticky uvažovat o naší existenci na Zemi (Quessada et al., 2008). Dynamický výzkum na poli paleoantropologie navíc poskytuje velmi podnětné zázemí pro pochopení vědeckého způsobu práce, založeného na tvorbě hypotéz a jejich falzifikaci (DeSilva, 2004; Pobiner, 2016).

\section{ZÁVĚR}

Obsahová analýza tématu vzniku a vývoje člověka ve 14 českých učebnicích dějepisu odhaluje množství nepřesností, zastaralých informací i faktických chyb, které 
učební texty obsahují. Pokud bychom měly shrnout, jaké hlavní nedostatky jsme objevily v českých učebnicích dějepisu, můžeme uvést následující: Vývoj člověka je obvykle podáván jako lineární řada jednoho druhu přecházejícího v jiný, což již neodpovídá dnešnímu stavu poznání. V kombinaci s tvrzením, že člověk je „evoluční vrchol stvoření" může vést tato představa $\mathrm{k}$ mylným závěrům, že evoluce člověka či živočichů obecně již skončila, a že objevení se druhu $H$. sapiens bylo plánovaným cílem evolučního procesu, což může komplikovat relevantní pochopení evoluce jako takové v pozdější výuce př́rodopisu a biologie. Často se setkáváme s tím, že učebnice neobsahují aktuální data, a dokonce zde nacházíme i zjevné chyby. Výčet druhů člověka bývá omezen jen na několik málo druhů a chybí zde nové objevy a teorie z posledních zhruba 50 let. Neandertálci jsou často z popisu vynecháváni nebo jsou popisováni jako poddruh Homo sapiens, což odporuje současnému stavu vědy. Učebnice často vyčleňuji samostatný druh Homo sapiens sapiens, jehož vznik datují na 40000 let BP. Tím mohou žáci nabýt mylného dojmu, že jeho předchůdce Homo sapiens již vyhynul. Problémem je také používání nejednotného názvosloví, zejména $\mathrm{v}$ českých ekvivalentech latinských názvů. Za jedno z nejzdařilejších zpracování tématu evoluce člověka $\mathrm{v}$ dějepisných učebnicích považujeme text $\mathrm{v}$ učebnici Dějepis 6 nakladatelství Fraus, autorské trojice Popelka, Kalistová, Soukup. I zde jsme ale narazily na drobné nedostatky a pro další vydání bychom doporučily mj. zařazení názorného náčrtku aktuálního fylogenetického stromu homininů nebo drobnou revizi prezentovaného spektra druhů. Učebnice jinak neobsahuje žádnou závažnější hrubou chybu.

Téma evoluce člověka je oblastí, která nám napomáhá pochopit sebe sama a kriticky přemýšlet o místě člověka zde na Zemi. Není proto zanedbatelné, prostřednictvím jakých fakt, obrazů nebo metafor s ním budou žáci seznamováni.

\section{PODĚKOVÁNí}

Výzkum byl podpořen Grantovou agenturou Univerzity Karlovy v Praze (projekt č. 279515).

\section{LITERATURA}

Alles, D. L., Stevenson, J. C. (2003). Teaching human evolution. Human evolution, 65(5), $333-339$.

Altmann, A. (1975). Metody a zásady ve výuce biologii. Praha: SPN.

Barton, N. H., Briggs, D. E. G., Eisen, J. A., Goldstein, D. B. \& Patel, N. H. (2007). Evolution. New York: Cold Spring Harbor Laboratory Press.

DeSilva, J. (2004). Interpreting evidence: an approach to teaching human evolution in the classroom. The American Biology Teacher, 66(4), 257-267.

Driscoll, M. P., Moallem, M. \& Dick, W. (1994). How does the textbook contribute to learning in a middle school science class? Contemporary Educational Psychology, 19(1), $79-100$.

Graf, D. (Ed.). (2011). Evolutionstheorie - Akzeptanz und Vermittlung im europäischen Vergleich. Berlin Heidelberg: Springer Spektrum. 
Leakey, R. E. F. (1973). Evidence for an Advanced Plio-Pleistocene Hominid from East Rudolf, Kenya. Nature, 242, 447-450.

Márquez, S., Pagano, A. S., Delson, E., Lawson, W. \& Laitman, J. T. (2014). The Nasal Complex of Neanderthals: An Entry Portal to their Place in Human Ancestry. The Anatomical Record, Special Issue The Vertebrate Nose: Evolution, Structure, and Function, 297(11), 2121-2137.

McBrearty, S. \& Brooks, A. S. (2000). The revolution that wasn't: a new interpretation of the origin of modern human behavior. Journal of Human Evolution, 39(5), 453-563.

Mikk, J. (2007). Učebnice: budoucnost národa. In J. Maňák \& P. Knecht (Eds.), Hodnocení učebnic (11-23). Brno: Paido.

Padian, K. (2013). Correcting some common misrepresentations of evolution in textbooks and the media. Evolution: Education and Outreach, 6(11).

Pertaglia, M. D., Haslam, M., Fuller, D. Q., Boivin, N. \& Clarkson, C. (2010). Out of Africa: new hypotheses and evidence for the dispersa of Homa sapiens along the Indian Ocean rim. Annals of Human biology, 37(3), 288-311.

Plutzer, E. \& Berkman, M. (2008). Evolution, creationism and the teaching of human origin in schools. Public Opinion Quarterly, 72(3), 540-553.

Pobiner, B. (2016). Accepting, understanding, teaching, and learning (human) evolution: ocstacles and opportunities. Yearbook of physical antropology, 159, S232-S274.

Průcha, J. (1998). Učebnice:Teorie a analýza edukačního média. Příručka pro studenty, učitele, autory učebnic a výzkumné pracovniky. Brno: Paido.

Quessada, M., Clément, P., Oerke, B. \& Valente, A. (2008). Human evolution in science textbooks from twelve different countries. Science Education International, 19(2), $147-162$.

Rámcový vzdělávací program pro základní vzdělávání. (2010). Česka republika. Dostupné z http://www.nuv.cz/file/133

Rámcový vzdělávací program pro gymnázia. (2007). Ceska republika. Dostupné z http://www.nuv.cz/file/159

Robertsonová, A. (2012). Evoluce - Př́běh člověka. Praha: Euromedia Group, k. s. Knižní klub v edici Universum.

Schwartz, J.H., Tattersall, I. (2010). Fossil evidence for the origin of Homo sapiens. American Journal of Physical Anthropology, 143(51), 94-121.

Sikorová, Z. (2007). Návrh seznamu hodnotících kritérií pro učebnice základních a středních škol. In J. Maňák \& P. Knecht (Eds.), Hodnocení učebnic (31-39). Brno: Paido.

Skoog, G. (2005). The coverages of human evolution in high school biology textbooks in the 20th century and in the state science standarts. Science $\&$ Education, 14, 395-422.

Soukup, V. (2015). Prehistorie rodu Homo. Praha: Karolinum.

Storch, V., Welsch, U. \& Wink, M. (2013). Evolutionsbiologie. Berlin Heidelberg: Springer Spektrum.

Svoboda, J. (1999). Čas lovců. Dějiny paleolitu, zvláště na Moravě. Brno: Akademie věd České republiky - Archeologický ústav Brno.

Svoboda, J. A. (2014). Předkové evoluce člověka. Praha: Academia. 
Vančata, V. (2005). Paleoantropologie a evoluční antropologie. Učební text pro studenty antropologických oborů University Karlovy. Praha: Universita Karlova v Praze, Pedagogická fakulta, katedra biologie a ekologické výchovy.

Woodward, A. (1986). Beyond Textbooks in Elementary Social Studies. Social Education, 50(1), 50-53.

RADKA MARTA DvoŘÁKovÁ, radka.marta@natur.cuni.cz

Univerzita Karlova v Praze, Pedagogická fakulta

Katedra biologie a environmentálních studií

M. D. Rettigové 4, 11639 Praha 1, Česká republika

Př́rodovědecká fakulta

Katedra učitelství a didaktiky biologie

Viničná 7, 12844 Praha 2, Česká republika

KarolínA ABSOLONOVÁ, karolina.absolonova@seznam.cz

Endokrinologický ústav

Národní 8, 11694 Praha 1, Česká republika 